\title{
Enthalpy and entropy contributions to the equilibrium of the hydrogen bonding interaction between 1-octylthymine and 9-octyladenine
}

\author{
Magali Salas, Barbara Gordillo,* and Felipe J. González* \\ Departamento de Química del Centro de Investigación y de Estudios Avanzados del I. P. N., Av. \\ Instituto Politécnico Nacional 2508, Apdo. Postal 14-740, C. P. 07360, México D. F., México \\ E-mail:ggordill@mail.cinvestav.mx; fgonzale@mail.cinvestav.mx \\ (received 05 Sep 03; accepted 30 Oct 03; published on the web 03 Nov 03)
}

\begin{abstract}
Hydrogen bonding interaction between 1-octylthymine (1) and 9-octyladenine (2) was analyzed by dynamic proton NMR spectroscopy. A mathematical model that takes into account the independent self-association of $\mathbf{1}$ and $\mathbf{2}$ was developed in order to determine the equilibrium constant of the interaction between 1-octylthymine and 9-octyladenine $\mathrm{K}_{\mathbf{1 - 2}}$.

The measurement of $\mathrm{K}_{1-2}$, in $\mathrm{CDCl}_{3}$, in the range of temperatures of -30 to $40{ }^{\circ} \mathrm{C}$ permitted estimation of the contributions of enthalpy $\Delta H^{0}=-6.74 \mathrm{kcal} / \mathrm{mol}$, and entropy $\Delta \mathrm{S}^{0}=-13.95 \mathrm{cal}$ $\mathrm{mol}^{-1} \mathrm{~K}^{-1}$, to the hetero-association process. From the enthalpic point of view the association of 1-octylthymine with 9-octyladenine is $0.56 \mathrm{kcal} / \mathrm{mol}$ stronger than the self-association of 1octylthymine, and $0.09 \mathrm{kcal} / \mathrm{mol}$ stronger than the self-association of 9-octyladenine. X-ray diffraction of a monocrystal of mixed 1-octylthymine and 9-octyladenine indicated that the interaction between these nucleobases in the solid state resemble Haschemeyer-Sobell more than Watson-Crick hydrogen bonding.
\end{abstract}

Keywords: H-Bonding, nucleobases, 1-octylthymine, 9-octyladenine, thymine-adenine adduct, association, thermodynamic parameters, crystal packing

\section{Introduction}

Hydrogen bonding plays a ubiquitous role in the assembly and molecular recognition properties of supramolecular structures, ${ }^{1-4}$ biomolecules, ${ }^{5-7}$ and nanomaterials. ${ }^{8-10}$

One of the most important biological processes, that is controlled by hydrogen bonding, is the selective recognition between the two strands of helical DNA. This weak non-covalent interaction is then responsible for the self-replication of DNA as well as the transcription of the information from a mother to a daughter cell. ${ }^{5}$ 
In 1954 Watson and Crick proposed that the nucleobases of DNA interact through a unique H-bonding that links a pyrimidine and purine at a time, by complementarity in shape, size, and number of bonding sites. Thus, thymine and adenine recognize each other forming two H-bonds and cytosine and guanine forming three (Scheme 1 ). ${ }^{7}$ Watson-Crick hydrogen bonding is not the only way of interaction between the nucleobases in DNA; however, they give rise to the most common tertiary structure, the helical B-form of DNA., ${ }^{71}$ The other important H-bonding interactions between nucleobases are the Hoogsteen, and the Haschemeyer-Sobell. Examples of these configurations are included in Scheme 2 and 3, respectively. ${ }^{12,13}$
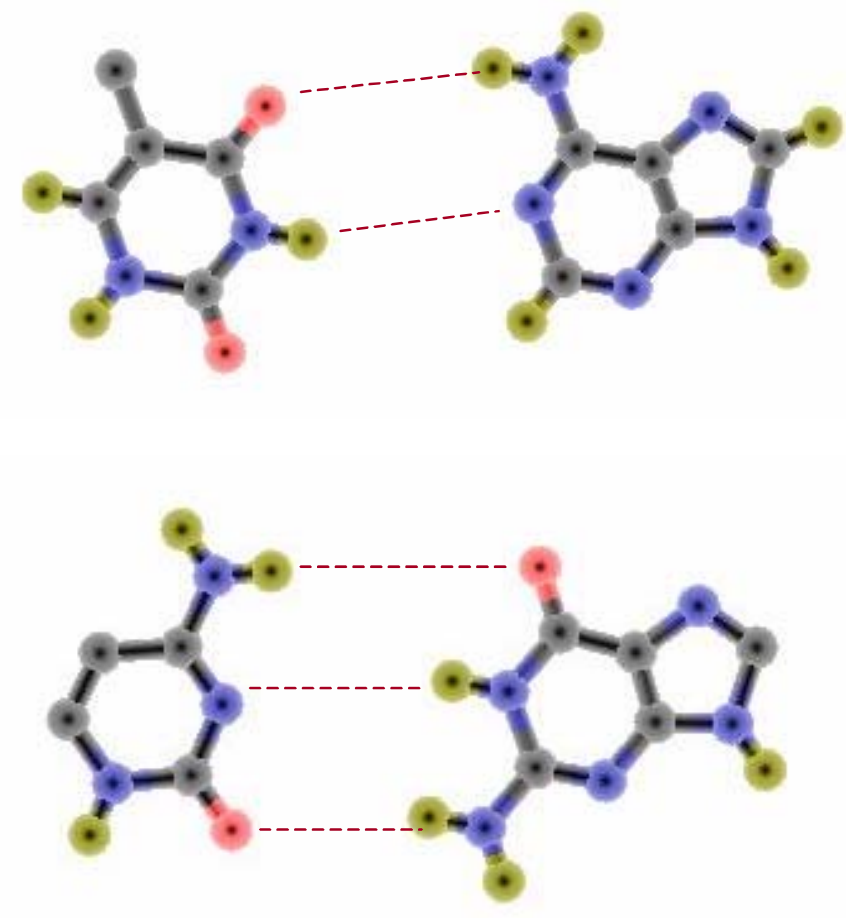

Scheme 1. Watson-Crick H-bonding in nucleobases.

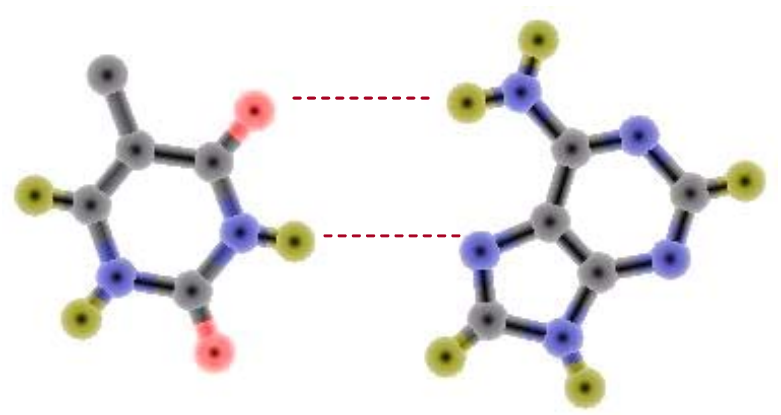

Scheme 2. Hoogsteen H-bonding in the adduct thymine-adenine. 


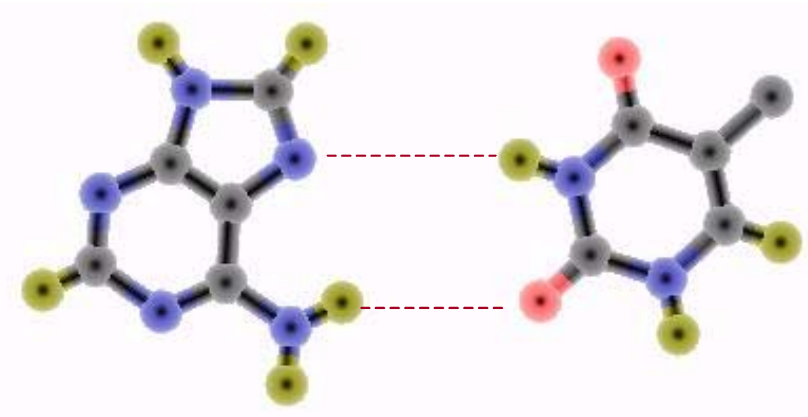

Scheme 3. Haschemeyer-Sobell (or reverse Hoogsteen) H-bonding in the adduct thymineadenine.

To this date, there have been several research groups interested in the experimental determination of the equilibrium contant of the nucleobases of DNA. Table 1 shows a compilation of methods and thermodynamic parameters, reported for the interaction of thymine and adenine. In addition, Sartorious and Schneider ${ }^{16}$ have proposed an empirical rule to determine a $\mathrm{K}$ value for the $\mathrm{H}$-bonding interaction in a substrate-receptor system. The $\mathrm{K}$ value calculated, by this rule, for the pair thymine-adenine is $56.62 \mathrm{M}^{-1}$.

Table 1. Determination of the K of equilibrium for the pair thymine/adenine

\begin{tabular}{llccccc}
\hline Compound & Solvent & Method & $\begin{array}{c}\Delta \mathrm{H}^{\circ} \\
(\mathrm{kcal} / \mathrm{mol})\end{array}$ & $\begin{array}{c}\Delta \mathrm{G}^{\circ} \\
(\mathrm{kcal} / \mathrm{mol})\end{array}$ & $\begin{array}{c}\mathrm{K}_{\mathrm{TA}} \\
(\mathrm{L} / \mathrm{mol})\end{array}$ & Ref. \\
\hline $\begin{array}{l}\text { 9-Ethyladenine- } \\
\text { 1-cyclohexylthymine }\end{array}$ & $\begin{array}{l}\mathrm{CDCl}_{3} \\
\left(25{ }^{\circ} \mathrm{C}\right)\end{array}$ & $\mathrm{IR}$ & - & -2.88 & 130 & 14 \\
$\begin{array}{l}\text { 9-Ethyladenine- } \\
\text { 1-cyclohexylthymine }\end{array}$ & $\begin{array}{l}\mathrm{CDCl}_{3} \\
\left(-56{ }^{\circ} \mathrm{C}\right)\end{array}$ & ${ }^{1} \mathrm{H}$ NMR & - & -2.95 & 940 & 15 \\
$\begin{array}{l}\text { 9-Hexyladenine- } \\
\text { 1-hexylthymine }\end{array}$ & $\begin{array}{l}\mathrm{CDCl}_{3} \\
\left(25{ }^{\circ} \mathrm{C}\right)\end{array}$ & $\begin{array}{c}\text { NMR } \\
\text { titration }\end{array}$ & - & -2.1 & 33.50 & 16 \\
$\begin{array}{l}\text { 1-Methyladenine- } \\
\text { 1-methylthymine }\end{array}$ & $\begin{array}{l}\text { Water } \\
\left(25{ }^{\circ} \mathrm{C}\right)\end{array}$ & $\begin{array}{c}\text { Refractive } \\
\text { method }\end{array}$ & $-7.3 \pm 0.2$ & - & - & 17 \\
$\begin{array}{l}\text { 1-Methyladenine- } \\
\text { 1-methylthymine }\end{array}$ & $\begin{array}{l}\text { Water } \\
\left(25{ }^{\circ} \mathrm{C}\right)\end{array}$ & $\begin{array}{c}\text { Mass } \\
\text { spectrometry }\end{array}$ & -13.0 & - & - & 18 \\
\hline
\end{tabular}


Even though $\mathrm{K}$ of equilibrium (eq. 1) provides information regarding the strength of the interaction between two associated species, the enthalpy $\Delta \mathrm{H}^{0}$ term is more relevant in order rationalize it, because, in most of the cases, it does not depend on the solvent or the temperature which the determination is done. ${ }^{19}$ In this regard, there are only few reports of the interaction between thymine-adenine. Furthermore, values of the reported enthalpy for the pair thymineadenine, vary widely $(-7.3$ vs. $-13 \mathrm{kcal} / \mathrm{mol}$ ) as shown in Table 1 , therefore we deemed it important of to re-evaluate them. Thus, reported in this work is a mathematical method to analyze the proton NMR data obtained from the H-bonding interaction between 1-octylthymine (1) and 9-octyladenine (2). The method takes into account the equilibrium constant of the selfassociation of each nucleobase $K_{1-1}$ and $K_{2-2}$. The NMR experiments were carried out at several temperatures, to be able to obtain the enthalpy and entropy contributions for the self-association of (1) or (2), as well as the cross-linked (1-2) interaction. X-ray structures of 9-octyladenine and the 1-octylthymine/9-octyladenine pair are also reported.

$$
\Delta \mathbf{G}^{\mathbf{0}}=-\mathbf{R} \mathbf{T} \ln \mathbf{K}=\Delta \mathbf{H}^{\mathbf{0}}-\mathbf{T} \Delta \mathbf{S}^{\mathbf{0}}
$$

\section{Results and Discussion}

\section{Synthesis}

1-Octylthymine (1) and 9-octyladenine (2) were prepared as shown in Scheme 4. Compound 1 was purified by column chromatography using hexane/ethyl acetate (80:20) as solvent (80\% yield). Sample 2 was obtained as crystals through recrystallization from acetonitrile, in a 85\% yield. Compound $\mathbf{2}$ was analyzed by X-ray diffraction, and the structure of $\mathbf{1}$ is already reported. ${ }^{20}$ A mixed sample of 1-octylthymine/ 9-octyladenine (1:1) afforded good quality crystals for X-ray diffraction when recrystallized from DMSO.

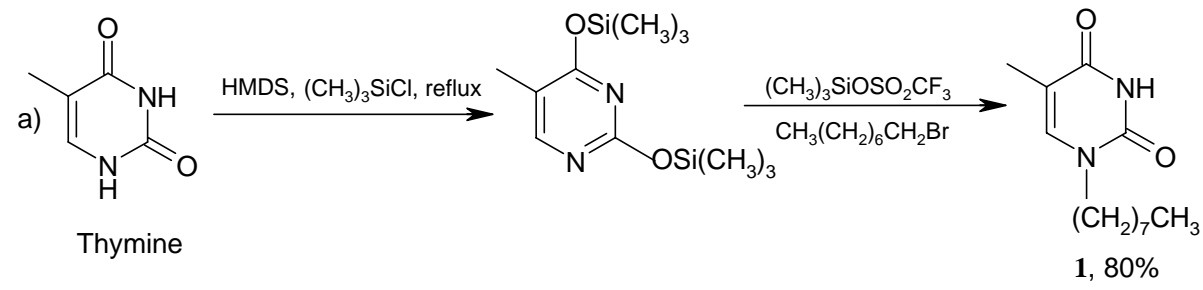

b)

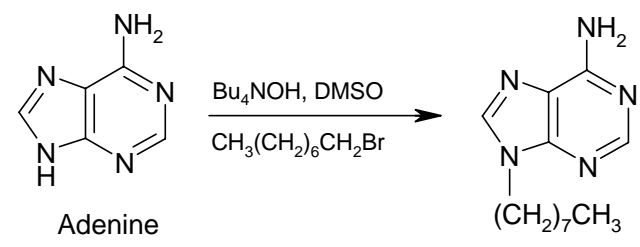

Scheme 4. Synthesis of (a) n-octylthymine; (b) n-octyladenine. 


\section{Thermodynamic parameters of the self-association process}

The equilibrium constants for the self-association of 1 -octylthymine $K_{1-1}$ or 9-octyladenine $K_{2-2}$ (eq. 2 and 3) were evaluated by means of the observed chemical shift $\left(\delta_{\text {obs }}\right)$ of the proton $\mathrm{NH}$ for 1-octylthymine and $\mathrm{NH}_{2}$ for 9-octyladenine. Equation 4 relates $\delta_{\text {obs }}$ with the percentage of the free $\mathrm{N}$ and self-associated $\mathrm{N}-\mathrm{N}$ species in equilibrium.

The proton NMR spectra of the samples were recorded in $\mathrm{CDCl}_{3}$ at several concentrations and temperatures. The proton chemical shift for the NH group of the free 1-octylthymine $\left(\delta_{1}\right)$ was taken as $7.90 \mathrm{ppm}$; this is the chemical shift of the more diluted solution $\left(1 \times 10^{-3} \mathrm{M}\right)$ at the highest temperature $\left(40{ }^{\circ} \mathrm{C}\right)$ registered. ${ }^{21}$ For 9-octyladenine, the proton chemical shift for the $\mathrm{NH}_{2}$ group $\left(\delta_{2}\right)$ was taken as $5.53 \mathrm{ppm}$ (solution $1 \times 10^{-4} \mathrm{M}$, at $40{ }^{\circ} \mathrm{C}$ ). ${ }^{21}$ We believe that these chemical shifts are indeed of the free species because the chemical shift of both $\mathrm{NH}$ and $\mathrm{NH}_{2}$ signals at low concentrations and low temperature $\left(0\right.$ to $\left.-30{ }^{\circ} \mathrm{C}\right)$ remained practically the same $( \pm$ $0.15 \mathrm{ppm}$ of variation in both cases). On the other hand, the proton chemical shift of the $\mathrm{NH}$ group for the self-association of 1-octylthymine $\left(\delta_{1-1}\right)$ was taken as $11.17 \mathrm{ppm}$, because this signal was registered at the highest concentration studied and the lowest temperature $(0.5 \mathrm{M}$ at $\left.50{ }^{\circ} \mathrm{C}\right) .{ }^{21}$ Similarly, for the self-association of 9-octyladenine $\left(\delta_{2-2}\right)$, the $\delta_{\mathrm{NH} 2}$ was taken as 7.45 ppm $\left(0.5 \mathrm{M}\right.$ at $\left.-10^{\circ} \mathrm{C}\right) .^{21}$

$$
\begin{gathered}
\mathbf{N}+\mathbf{N} \stackrel{\mathbf{K}_{\mathrm{N}-\mathrm{N}}}{=} \mathrm{N}-\mathrm{N} \\
\text { Where } \mathrm{N}=\mathbf{1} \text { or } \mathbf{2} \\
\mathbf{K}_{\mathrm{N}-\mathrm{N}}=\frac{\mathbf{C}_{\mathrm{N}-\mathrm{N}}}{\left(\mathrm{C}_{\mathrm{N}}\right)^{2}}=\frac{\mathrm{C}_{\mathrm{N}-\mathrm{N}}}{\left(\mathrm{C}_{\mathrm{No}}-\mathrm{C}_{\mathrm{N}-\mathrm{N}}\right)^{2}} \\
\delta_{\mathrm{obs}}=\frac{\mathbf{C}_{\mathrm{N}}}{\mathbf{C}_{\mathrm{No}}} \delta_{\mathrm{N}}+\frac{\mathrm{C}_{\mathrm{N}-\mathrm{N}}}{\mathrm{C}_{\mathrm{No}}} \delta_{\mathrm{N}-\mathrm{N}}
\end{gathered}
$$

The equilibrium constant for self-association (eq. 3) depends on the initial concentration of the solution $\left(\mathrm{C}_{\mathrm{No}}=0.1 \mathrm{M}\right)$. By rearranging equation 4 , the concentration of self-associated species, can be calculated through equation 5 .

$$
\mathrm{C}_{\mathrm{N}-\mathrm{N}}=\left(\frac{\delta_{\mathrm{obs}}-\delta_{\mathrm{N}}}{\delta_{\mathrm{N}-\mathrm{N}}-\delta_{\mathrm{N}}}\right) \mathrm{C}_{\mathrm{No}}
$$

The observed changes in the chemical shift $\left(\delta_{\text {obs }}\right)$ for the $\mathrm{NH}$ signal with temperature, that are involved in the interaction of (1-1) at the intermediate concentration of $0.1 \mathrm{M}$, are shown in Table 2. As for the interaction of (2-2) at the same concentration, the results are collected in Table 3. Calculations of $\mathrm{C}_{\mathbf{1 - 1}}$ or $\mathrm{C}_{\mathbf{2 - 2}}$ were performed using equation 5 , and the values were 
substituted in equation 3 to calculate the equilibrium constants at different temperatures (Table 2 and 3). By applying the Gibbs equation 1, we were able to calculate the free energy $\left(\Delta G^{0}\right)$ involved in the self-association of 1-octylthymine (Table 2) and 9-octyladenine (Table 3). A comparison of these values at $20{ }^{\circ} \mathrm{C}$, indicate that the self-association of (1) in $\mathrm{CDCl}_{3}$ is stronger than the self-association of (2) by $0.27 \mathrm{kcal} / \mathrm{mol}$.

Table 2. ${ }^{1} \mathrm{H}$ NMR Chemical shifts (in ppm) for 1-octylthymine (1), in $\mathrm{CDCl}_{3}$, and the calculated equilibrium constant $\mathrm{K}_{\mathbf{1 - 1}}$ of the self-association process

\begin{tabular}{cccc}
\hline Temperature $(\mathrm{K})$ & $\begin{array}{c}\text { Chemical Shift } \\
\left(\delta_{\mathrm{NH}}\right)\end{array}$ & $\begin{array}{c}\mathrm{K}_{\mathbf{1 - 1}} \\
\left(\mathrm{M}^{-1}\right)\end{array}$ & $\begin{array}{c}\Delta \mathrm{G}_{\mathbf{1 - 1}}^{\mathrm{1}} \\
(\mathrm{kcal} / \mathrm{mol})\end{array}$ \\
\hline 223 & 10.66 & 328.12 & -2.57 \\
233 & 10.48 & 179.14 & -2.40 \\
243 & 10.28 & 100.14 & -2.22 \\
253 & 10.05 & 57.09 & -2.03 \\
263 & 9.83 & 35.10 & -1.86 \\
273 & 9.61 & 22.57 & -1.69 \\
283 & 9.40 & 15.77 & -1.55 \\
293 & 9.22 & 11.11 & -1.40 \\
303 & 9.05 & 8.28 & -1.27 \\
313 & 8.89 & 6.12 & -1.13 \\
\hline
\end{tabular}

Table 3. ${ }^{1} \mathrm{H}$ NMR Chemical shifts (in ppm) for 9-octyladenine (2), in $\mathrm{CDCl}_{3}$, and the calculated equilibrium constant $\mathrm{K}_{2-2}$ of the self-association process

\begin{tabular}{cccc}
\hline Temperature $(\mathrm{K})$ & $\begin{array}{c}\text { Chemical Shift } \\
\left(\delta_{\mathrm{NH} 2}\right)\end{array}$ & $\begin{array}{c}\mathrm{K}_{2-2} \\
\left(\mathrm{M}^{-1}\right)\end{array}$ & $\begin{array}{c}\Delta \mathrm{G}^{\mathrm{o}}{ }^{2-2} \\
(\mathrm{kcal} / \mathrm{mol})\end{array}$ \\
\hline 253 & 6.71 & 40.10 & -1.86 \\
263 & 6.55 & 23.99 & -1.66 \\
273 & 6.40 & 14.88 & -1.46 \\
283 & 6.26 & 9.88 & -1.29 \\
293 & 6.14 & 6.92 & -1.13 \\
303 & 6.02 & 4.44 & -0.90 \\
313 & 5.92 & 3.12 & -0.71 \\
\hline
\end{tabular}

The evaluation of the enthalpy $\left(\Delta \mathrm{H}^{0}\right)$, and entropy $\left(\Delta \mathrm{S}^{0}\right)$ components for the self-association process was performed through the van't Hoff equation (6). The linear regression value for the plot $\ln \mathrm{K}$ vs. $1 / \mathrm{T}$ was excellent for 1-octylthymine $(\mathrm{r}=0.999)$, as well as for 9-octyladenine $(\mathrm{r}=$ 0.999). The data have a standard deviation of 0.057 for 1-octylthymine and 0.021 for 9- 
octyladenine (average from 3 data set). The enthalpy was calculated from the slope of the curves and the entropy from the intercept to the ordinate. Values are shown in Scheme 5.

$$
\ln \mathbf{K}=-\frac{\Delta \mathbf{H}^{\mathbf{0}}}{\mathbf{R T}}+\frac{\Delta \mathbf{S}^{\mathbf{0}}}{\mathbf{R}}
$$

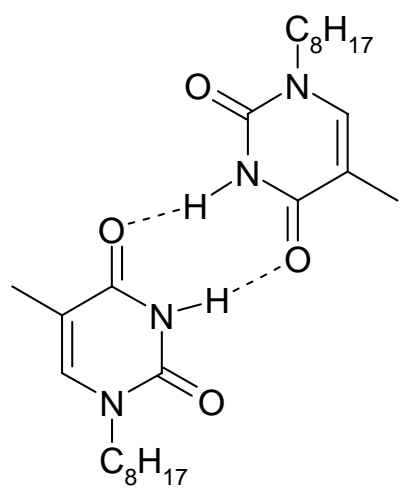

$$
\begin{aligned}
\Delta \mathrm{H}^{\mathrm{o}}{ }_{1-\mathbf{1}} & =-6.18 \mathrm{kcal} / \mathrm{mol}^{-1} \\
\Delta \mathrm{S}^{\mathrm{o}}{ }_{\mathbf{1 - 1}} & =-16.27 \mathrm{cal} \mathrm{mol}{ }^{-1} \mathrm{~K}^{-1}
\end{aligned}
$$

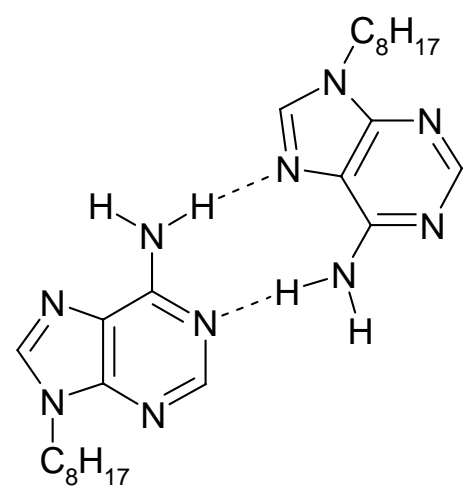

$\Delta \mathrm{H}^{\mathrm{o}}{ }_{2-2}=-6.65 \mathrm{kcal} / \mathrm{mol}$ $\Delta \mathrm{S}_{2-2}^{\mathrm{o}}=-18.94 \mathrm{cal} \mathrm{mol}^{-1} \mathrm{~K}^{-1}$

Scheme 5. Enthalpy and entropy values of the self-association of $n$-octylthymine and $n$ octyladenine.

As it can be observed, the values of enthalpy for the self-association process indicate that the H-bonding linking between two 9-octyladenines are $0.47 \mathrm{kcal} / \mathrm{mol}$ more stable than the one between two 1-octylthymines; however, as expected, the formation of the dimers (1-1) or (2-2) is not favored by entropy. Actually, entropy disfavors the adenine more than the thymine homo adduct $\left(\Delta \Delta \mathrm{S}^{0}=2.67 \mathrm{cal} \mathrm{mol}^{-1} \mathrm{~K}^{-1}\right)$, so that the free energy ends by favoring the self-association of thymine over the adenine, at least in $\mathrm{CDCl}_{3}$, as it was observed above. On the other hand, $\mathrm{T} \Delta \mathrm{S}^{\mathrm{O}}$ contributions at $25{ }^{\circ} \mathrm{C}$ are, for 1 -octylthymine $(-4.85 \mathrm{kcal} / \mathrm{mol})$ and for 9 -octyladenine ($5.64 \mathrm{kcal} / \mathrm{mol}$ ); they are indeed similar to the enthalpy of their corresponding systems, as it would have been expected for non-covalent interactions.

The fact that the enthalpies of both self-association processes are close to one another $(-6.18$ vs. - $6.65 \mathrm{kcal} / \mathrm{mol}$ ) is indicating that at least the number of H-bonding interactions in each homo adduct is the same. The most likely ways for self-association between the nucleobases are the symmetric or the asymmetric H-bonding structures of Scheme 6. Nevertheless, the symmetric and asymmetric interactions are not the same, both configurations lead to two [O...H-N] for thymine and two $[\mathrm{N}-\mathrm{H} \ldots \mathrm{N}]$ for adenine. Thus we can conclude that every [O...H-N] bonding contributes with $3.09 \mathrm{kcal} / \mathrm{mol}$ of enthalpy to the stabilization of the adduct (1-1) and that the interaction [N...H-N] contributes with $3.33 \mathrm{kcal} / \mathrm{mol}$ to the stabilization of (2-2). In short, we 
found that the H-bonding [N...H-N] is slightly stronger $(0.24 \mathrm{kcal} / \mathrm{mol})$ than the [O...H-N] interaction. An explanation for this behavior could rely on the distance of approach of the donoracceptor, which is shorter in the homo adduct of 9-octyladenine [(N...H-N) bond length $2.11 \AA$ (average), a value obtained from the X-ray structure below] than in the homo adduct of 1octylthymine $[(\mathrm{O} \ldots \mathrm{H}-\mathrm{N})$ bond length $2.86 \AA$ (average) $] .{ }^{20}$

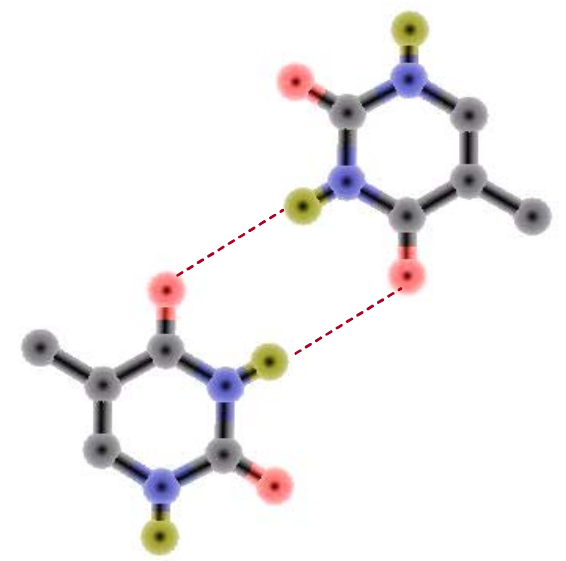

(T-T adduct) Symmetric

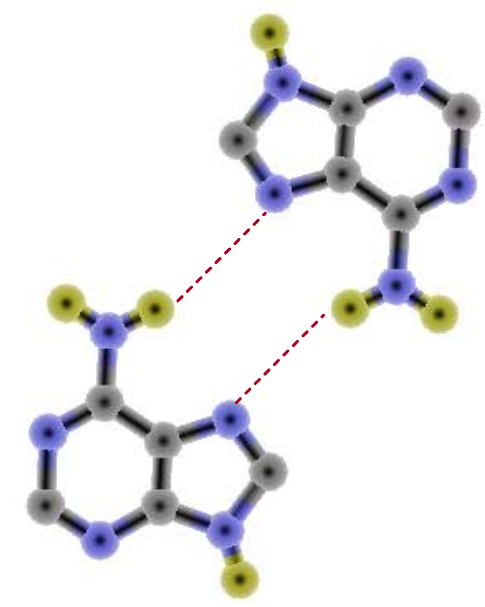

(A-A adduct) Symmetric

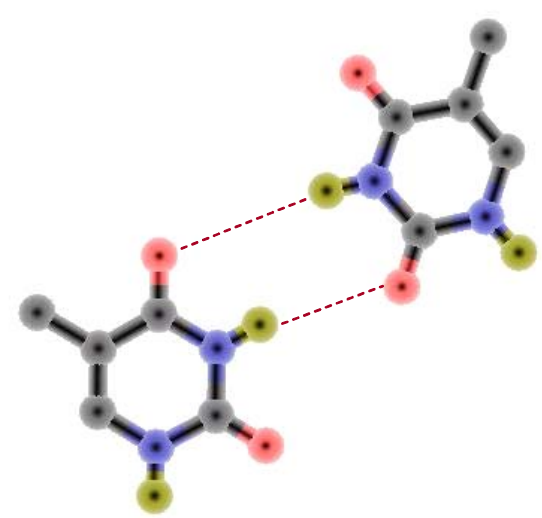

(T-T adduct) Asymmetric

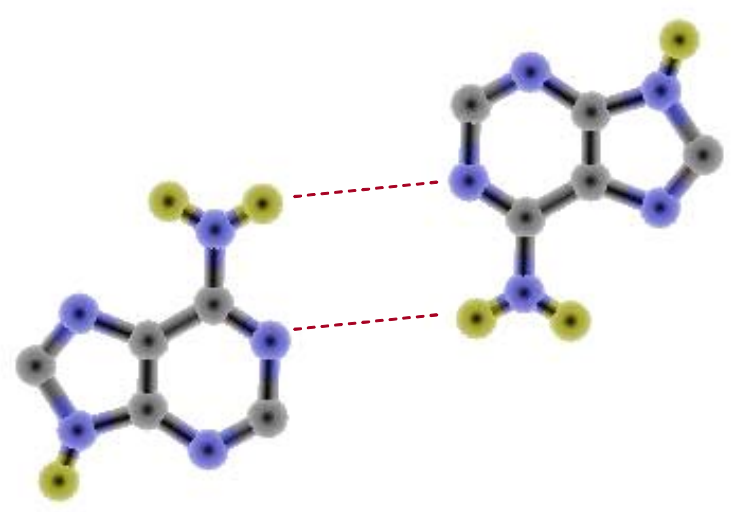

(A-A adduct) Asymmetric

Scheme 6. H-bonding structures for the homo adducts of thymine and adenine. 


\section{Thermodynamic parameters of the hetero-association process}

The H-bonding for the cross-linked system (1-2) was analyzed by a mathematical model that contemplates the equilibrium constants of the self-association process of each nucleobase, as it is shown in equation 7 . Thus, the equilibrium constants of each process can be calculated by means of equations 8 and 9.

$$
\begin{gathered}
\|_{(1-1)}^{(1)}+\underset{(2-2)}{(2)}= \\
\mathbf{K}_{1-2}=\frac{\mathbf{K}_{1-2}}{\mathbf{C}_{1-2} \mathbf{C}_{2}} \\
\mathbf{K}_{\mathbf{N}-\mathbf{N}}=\frac{\mathbf{C}_{\mathbf{N}-\mathbf{N}}}{\left(\mathbf{C}_{\mathbf{N}}\right)^{2}}
\end{gathered}
$$

Where $\mathrm{N}=\mathbf{1}$ or $\mathbf{2}$

The $\delta_{\text {obs }}$ was taken as the chemical shift of the $\mathrm{NH}$ group for $n$-octylthymine in the pair, and can be expressed in terms of the free and associated species, as shown in equation 10. The chemical shift for the mixed pair $\delta_{1-2}$ was taken as $14.32 \mathrm{ppm}$, this value was obtained from the $\mathrm{NH}$ signal of 1-octylthymine, in an independent experiment in which the proton NMR spectra of mixed 1-octylthymine/9-octyladenine $(1: 8)$ was held at high concentration $(0.5 \mathrm{M}) .{ }^{21}$ If we consider the initial concentration $\mathrm{C}_{10}=0.1 \mathrm{M}$, and the previously obtained chemical shifts of the free $\delta_{1}=7.90 \mathrm{ppm}$ and self-associated 1-octylthymine $\delta_{1-1}=11.17 \mathrm{ppm}$ respectively, equations 11 and 12 can be derived and used to characterize the system in the equilibrium.

$$
\begin{aligned}
& \delta_{\text {obs }}=\frac{\mathbf{C}_{1}}{\mathbf{C}_{1 \mathbf{0}}} \delta_{1}+\frac{\mathbf{C}_{1-1}}{\mathbf{C}_{1 \mathbf{0}}} \delta_{1-1}+\frac{\mathbf{C}_{1-2}}{\mathbf{C}_{1 \mathbf{0}}} \delta_{1-2} \\
& \delta_{\text {obs }}=79 \mathbf{C}_{1}+111.7 \mathbf{C}_{1-1}+143.2 \mathbf{C}_{1-2} \\
& \mathbf{C}_{1-2}=\mathbf{C}_{1 \mathbf{0}}-2 \mathbf{C}_{1-1}-\mathbf{C}_{1}
\end{aligned}
$$

The value of $\mathrm{K}_{\mathbf{1 - 2}}$ was calculated from an iterative method. Proposed initial values of $\mathrm{C}_{\mathbf{1}}$ were used to perform the calculation of $\mathrm{C}_{\mathbf{1 - 1}}$, according to equation $9 . \mathrm{C}_{\mathbf{1 - 2}}$ was then calculated 
according to equation 12. These values were substituted in equation 11 to obtain a calculated chemical shift $\delta_{\text {cal. }}$. Ultimate values were those obtained when convergence was reached, that is, when $\delta_{\text {calc }}=\delta_{\text {obs }} \pm 0.01$. Once $C_{1}$ and $C_{1-2}$ are defined by this procedure, $C_{2}$ was determined by solving the second degree equation 13 , which finally allowed us to calculate the equilibrium constant $\mathrm{K}_{1-2}$ (equation 8).

$$
\mathbf{C}_{2}=\mathbf{C}_{2 \mathbf{o}}-2 \mathbf{C}_{2-2}-\mathbf{C}_{1-2}=\mathbf{C}_{2 \mathbf{o}}-2 \mathbf{K}_{2-2} \mathbf{C}_{2}{ }^{2}-\mathbf{C}_{1-2}
$$

The chemical shift variation of the NH signal for the 1-octylthymine in the mixed (1)/(2) solution ( $0.1 \mathrm{M}$ of each compound) at different temperatures is summarized in Table 4. The $\Delta \mathrm{G}^{\circ}$ at $20{ }^{\circ} \mathrm{C}$ is $-2.64 \mathrm{kcal} / \mathrm{mol}$, around $1.2-1.5 \mathrm{kcal} / \mathrm{mol}$ stronger than the self-association of the nucleobases. This value matches well with those reported in Table 1 and the calculated by the empirical rule of Sartorius and Schneider $\left(\Delta \mathrm{G}_{25}{ }^{\circ}=-2.39 \mathrm{kcal} / \mathrm{mol}\right) .{ }^{16}$

Table 4. ${ }^{1} \mathrm{H}$ NMR Chemical shift (in ppm) for 1-octylthymine (1)/9-octyladenine (2) in $\mathrm{CDCl}_{3}$, and the calculated equilibrium constant $\mathrm{K}$ of the association process

\begin{tabular}{cccc}
\hline Temperature $(\mathrm{K})$ & $\begin{array}{c}\text { Chemical shift } \\
\left(\delta_{\mathrm{NH}}\right)\end{array}$ & $\begin{array}{c}\mathrm{K}_{1-2} \\
\left(\mathrm{M}^{-1}\right)\end{array}$ & $\begin{array}{c}\Delta \mathrm{G}_{1-2} \\
(\mathrm{kcal} / \mathrm{mol})\end{array}$ \\
\hline 243 & 13.85 & 1211.20 & -3.43 \\
253 & 13.66 & 574.38 & -3.19 \\
263 & 13.45 & 326.64 & -3.02 \\
273 & 13.21 & 198.30 & -2.87 \\
283 & 12.95 & 131.28 & -2.74 \\
293 & 12.71 & 93.57 & -2.64 \\
303 & 12.40 & 66.52 & -2.53 \\
313 & 12.10 & 49.86 & -2.43 \\
\hline
\end{tabular}

The van't Hoff's curve for the system is shown in Figure $1(\mathrm{r}=0.997)$, the enthalpy $\Delta \mathrm{H}^{0}{ }_{\mathbf{1 - 2}}$ and entropy $\Delta \mathrm{S}^{0}{ }_{1-2}$ contributions were calculated as $-6.74 \mathrm{kcal} / \mathrm{mol}$ and $-13.95 \mathrm{cal} \mathrm{mol}^{-1} \mathrm{~K}^{-1}$, respectively. If a comparison of enthalpy values between the hetero and homo association is made, we can conclude that even though there are also two hydrogen bonding interactions in the pair thymine-adenine (Scheme 1), the enthalpy is favoring this cross linked system over the independent self-association for $0.56 \mathrm{kcal} / \mathrm{mol}$ in the case of 1-octylthymine and for 0.09 $\mathrm{kcal} / \mathrm{mol}$ in the case of 9-octyladenine. Regardless of structure (Schemes 1-3), the types of $\mathrm{H}$ bonding in the pair thymine-adenine are $[\mathrm{O} \ldots \mathrm{H}-\mathrm{N}]$ and $[\mathrm{N} . . \mathrm{H}-\mathrm{N}]$, thus by taking the previously calculated enthalpy contribution of $-3.09 \mathrm{kcal} / \mathrm{mol}$ for $[\mathrm{O} . . . \mathrm{H}-\mathrm{N}]$ and $-3.33 \mathrm{kcal} / \mathrm{mol}$ for [N...H-N], the calculated $\Delta \mathrm{H}^{0}$ is $-6.42 \mathrm{kcal} / \mathrm{mol}$. The small difference between the calculated and experimental enthalpy $(0.32 \mathrm{kcal} / \mathrm{mol})$ is due to subtle changes in H-bonding distances which are smaller in the 1-octylthymine/9-octyladenine pair than in the homo pairs $[(\mathrm{O} . . \mathrm{H}-\mathrm{N})=2.09 \AA$ 
(thymine-adenine) vs. $2.86 \AA$ (thymine-thymine) ${ }^{20}$ (N...H-N) $=1.94 \AA$ (thymine-adenine) $v s$. $2.11 \AA$ (adenine-adenine)] as it is observed in the X-ray structures shown below. These finding might certainly indicate, that the intrinsic nature of the H-bonding is not always the same, even though the same kind of species are involved in the interaction. The entropic contribution is also disfavoring less the interaction between the pyrimidine-purine bases (1-2), than the independent (1-1) or (2-2) association.

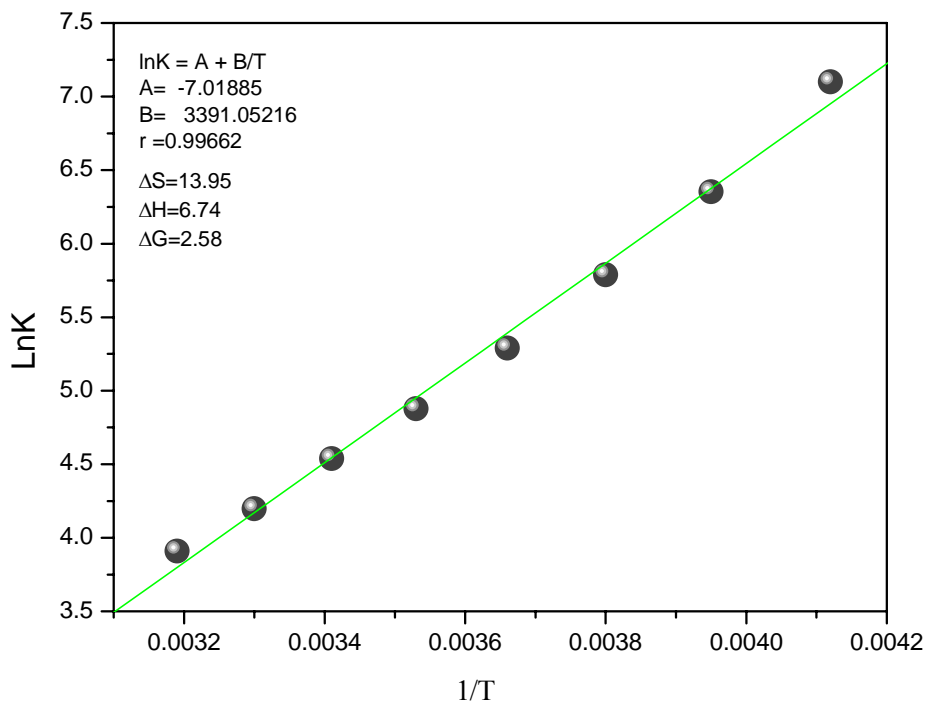

Figure 1. Linear regression $\operatorname{lnK}$ vs. 1/T for the mixed pair (1-2).

\section{X-Ray crystallography}

In order to gain support for the number and geometrical characteristics of hydrogen bonding interactions in the studied systems, we obtained good single crystals for the $n$-octyladenine and the mixed 1-octylthymine/9-octyladenine, (the X-ray structure of n-octylthymine is already reported $^{20}$ ). The ORTEP structures are shown in Figures 2 and 3, respectively. The adenine ring in Figure 2 is almost planar with a distortion of planarity of no more than 1.05 degrees, the $n$ octyl chain adopts a staggered conformation. In the 1:1 adduct of thymine-adenine (Figure 3 ) the thymine ring is more distorted from planarity (around 2 degrees) than the adenine ring. The $n$ octyl chains are arranged in such way that they minimize hindrance between them.

The H-bonding is visualized easily in the unit cell of the supramolecular structures shown in Figures 4 and 5. As observed, both 1:1 adducts (2-2) and (1-2) share two hydrogen bonds between the nucleobases. In the adenine homo adduct, the H-bonding interaction is asymmetric. On the other hand, the thymine-adenine adduct is in Haschemeyer-Sobell configuration. It is worth of note that although Watson-Crick configuration has been found in the X-ray structures of oligonucleotides of DNA, none of the adenine-thymine pairs studied in solid state, have the Watson-Crick configuration. ${ }^{12,13}$ 


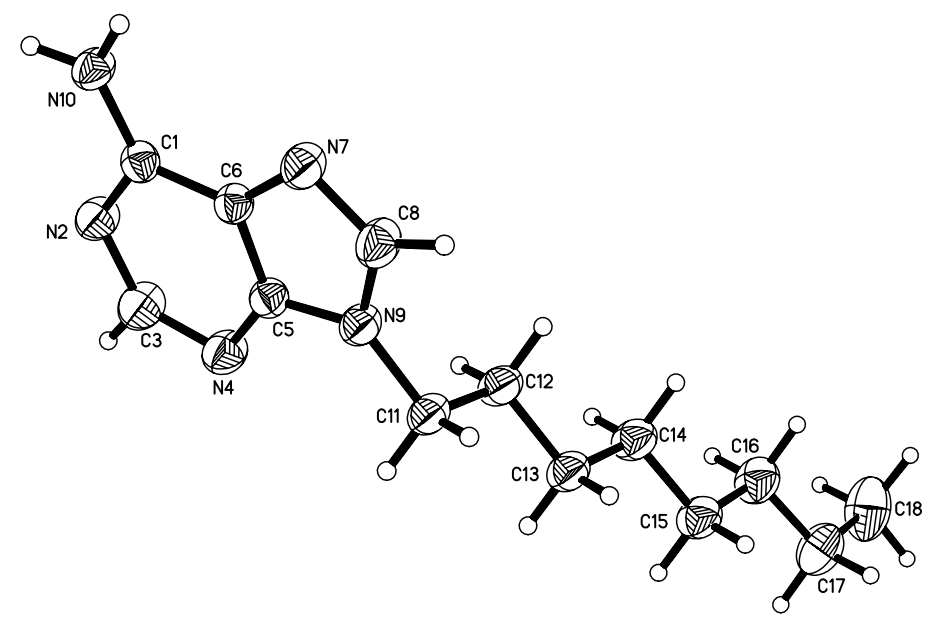

Figure 2. ORTEP projection of the molecular structure of 9-octyladenine (2). (Atoms H3, H8, H10a and H10b were located from a difference Fourier map and refined. All others $\mathrm{H}$ atoms were placed in calculated positions and refined using a riding model).
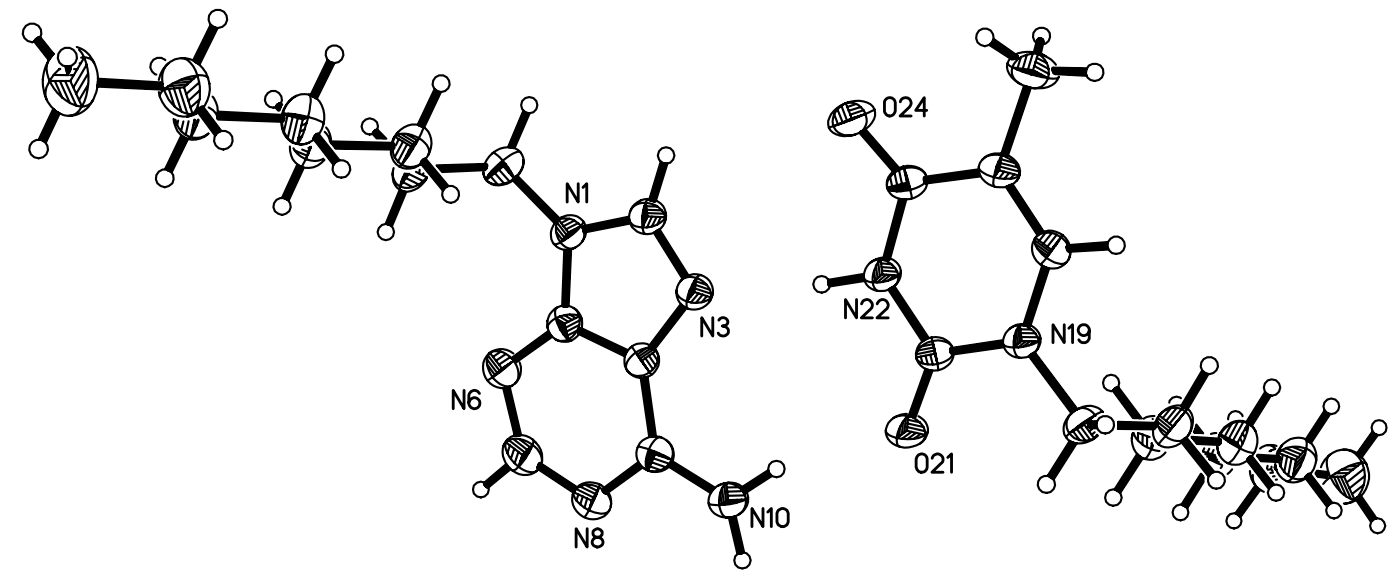

Figure 3. ORTEP projection of the molecular structure of mixed 1-octylthymine/9-octyladenine (1:1). (Atoms H2, H7, H10a, H10b, and H22 were located from a difference Fourier map and refined. All others $\mathrm{H}$ atoms were placed in calculated positions and refined using a riding model). 
In the structure of the 2-2 adduct (Figure 4), the purine-purine rings are approximately coplanar with dihedral angles in the range of 2.4-3.8 $\AA$. The bond distances between the nonbonded atoms $[\mathrm{N} \ldots \mathrm{N}]$ of the hydrogen bonds $[\mathrm{N} . . . \mathrm{H}-\mathrm{N}]$ are $2.95 \AA$ and $3.09 \AA$, and the bond distances between $\mathrm{H} . . \mathrm{N}$ are $2.08 \AA$ and $2.13 \AA$ respectively. These values are within the range of expected bond lengths for the $[\mathrm{N} . . . \mathrm{H}-\mathrm{N}]$ bonding $(3.1 \AA$ for $\mathrm{N} . . . \mathrm{N}$ and $2.2 \AA$ for $\mathrm{H} . . . \mathrm{N}) .{ }^{12,22}$ The N...H-N interaction is almost at $180^{\circ}\left[(\mathrm{N} 3 \ldots \mathrm{H}-\mathrm{N})\right.$ bond angle $=179.2^{\circ} ;(\mathrm{N} 10 \ldots \mathrm{H}-\mathrm{N})=$ $163.2^{\circ}$ ). Because of all these characteristics, the $\mathrm{H}$-bonding in the $\mathbf{2 - 2}$ adduct can be considered moderate and mainly electrostatic in nature. ${ }^{4}$ In the structure of $\mathbf{1 - 2}$ adduct (Figure 5) the purinepyrimidine rings are also almost coplanar (dihedral angles in the range of 3.4-6.75 $\AA$ ). The geometry of the $[\mathrm{N} \ldots \mathrm{H}-\mathrm{N}]$ interaction is as follow: bond angle $=172.3^{\circ}$, bond distances of nonbonded atoms $\mathrm{N} \ldots \mathrm{N}=2.89 \AA$; $\mathrm{N} . . . \mathrm{H}=1.93 \AA$. These values are in fact smaller than those expected for the bond lengths of [N...H-N] bonding (see above). As for the [O...H-N] interaction, the geometry is: bond angle $=164.3^{\circ}$, bond distances of non-bonded atoms O...N = $2.97 \AA ; \mathrm{O} \ldots \mathrm{H}=2.09 \AA$, and the expected values are very close [(O...H-N) $2.9 \AA$ for $\mathrm{O} \ldots \mathrm{N}$, and $2.0 \AA$ for $\mathrm{H} . . . \mathrm{O}] .^{12,22}$ From these values, it is evident that the H-bonding between 1octylthymine/9-octyladenine is also moderate; ${ }^{4}$ however, the fact that the approach between the thymine and adenine is at closer distance than the homo pairs of adenine or thymine $[(\mathrm{O} \ldots \mathrm{H}-\mathrm{N})$, $2.09 \AA$ vs. $2.86 \AA^{19}$ and (N...H-N) $1.94 \AA$ vs $2.11 \AA$ (average) for the hetero and homo adducts, correspondingly] stabilize the thymine-adenine complex over the thymine-thymine or adenineadenine complexes.

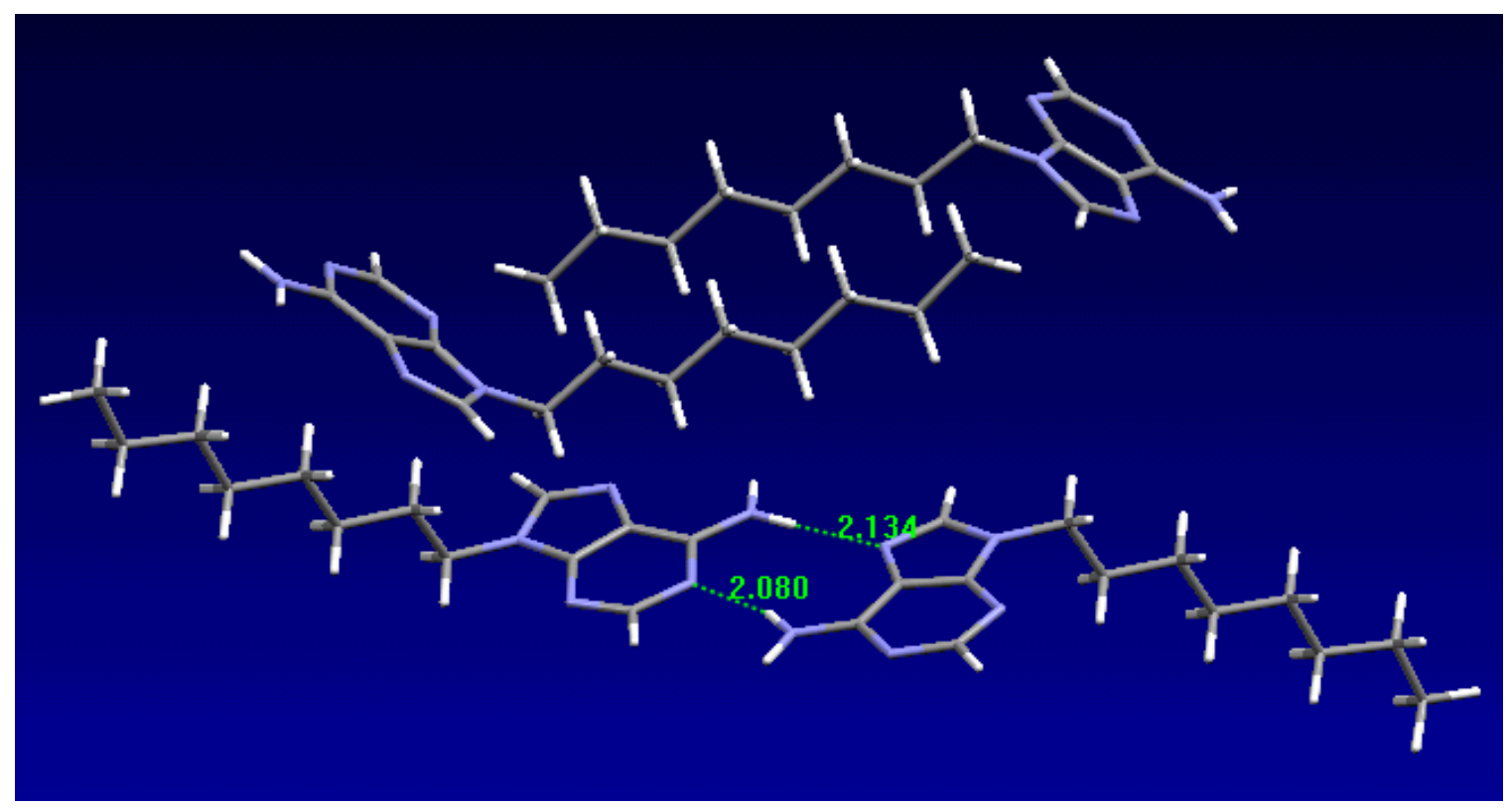

Figure 4. View of the crystal packing in the unit cell of 9-octyladenine (2). 


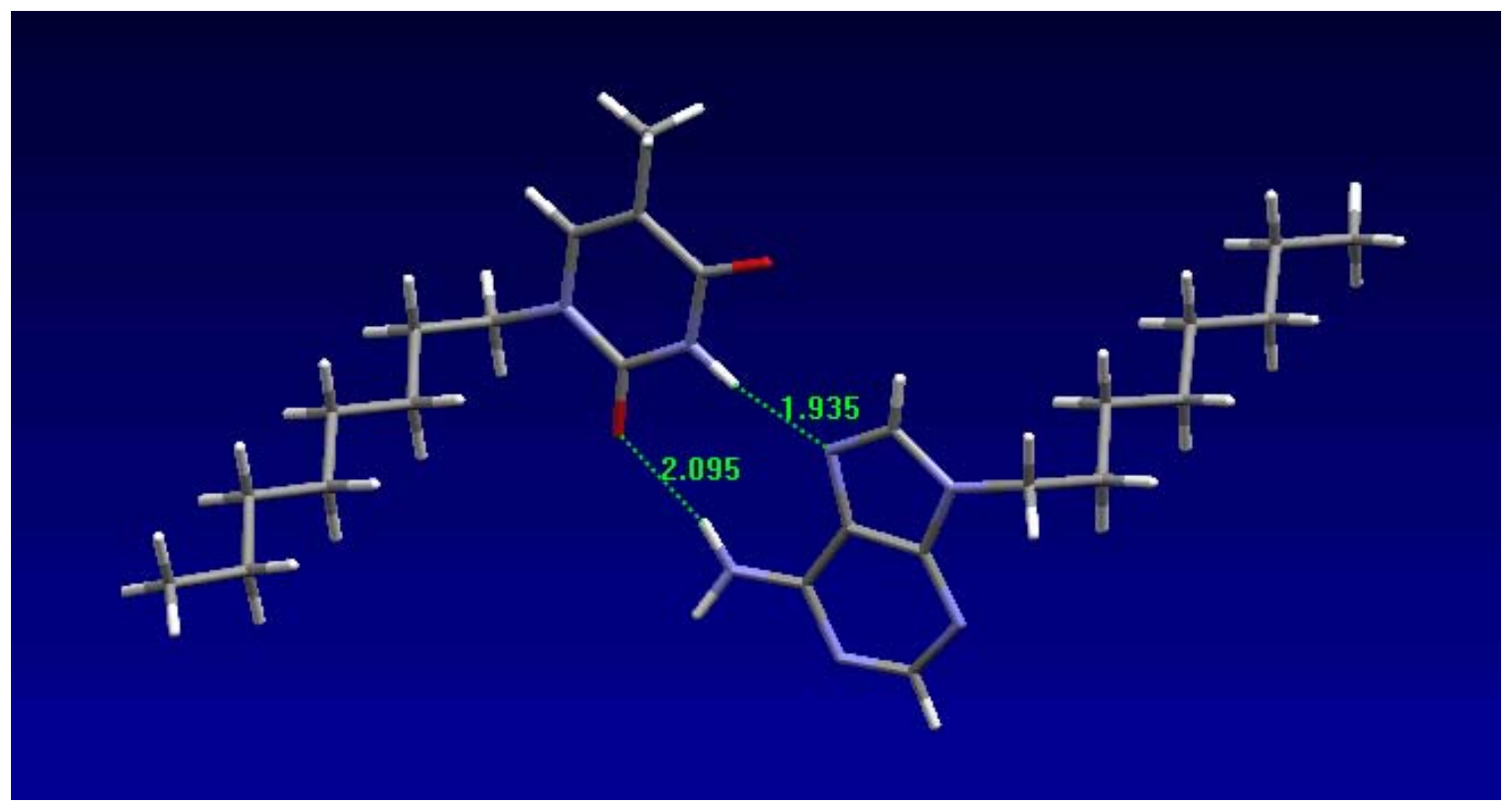

Figure 5. View of the crystal packing in the unit cell of the pair 1-octylthymine/9-octyladenine.

\section{Conclusions}

The enthalpy and entropy contributions to the equilibrium of the self-association of $n$ octylthymine $\left[\Delta \mathrm{H}^{0}{ }_{1-\mathbf{1}}=-6.18 \mathrm{kcal} / \mathrm{mol} ; \Delta \mathrm{S}^{0}{ }_{\mathbf{1 - 1}}=-16.27 \mathrm{cal} \mathrm{mol}^{-1} \mathrm{~K}^{-1}\right]$ and $n$-octyladenine $\left[\Delta \mathrm{H}^{0}{ }_{2-2}\right.$ $=-6.65 \mathrm{kcal} / \mathrm{mol} ; \Delta \mathrm{S}^{0}{ }_{2-2}=-18.94 \mathrm{cal} \mathrm{mol}^{-1} \mathrm{~K}^{-1}$ ] were evaluated, as well as those of the pair 1octylthymine/9-octyladenine $\left[\Delta \mathrm{H}^{0}{ }_{1-2}=-6.74 \mathrm{kcal} / \mathrm{mol} ; \Delta \mathrm{S}^{0}{ }_{\mathbf{1 - 2}}=-13.95 \mathrm{cal} \mathrm{mol}^{-1} \mathrm{~K}^{-1}\right]$. From these values, it is evident that in the competition for the $\mathrm{H}$-bonding association between nucleobases, the thymine-adenine pair is favored by enthalpy as compared to the self-association of each nucleobase. As expected, the entropy is not favoring the formation of neither the hetero nor the homo adducts. However, the fact that the loss of entropy is less in the pair thymineadenine helps of drive the equilibrium towards the hetero association. In the solid state, thymineadenine are closer in distance than the adenine-adenine or thymine-thymine dimers. That evidently is accompanied with stronger H-bonding between the hetero than the self-associated species. If we take these simple models to study the molecular recognition of the two strands of the helical DNA, we can conclude that the chemical nature of the linking sites is as important as the complement in shape or size in the H-bonding interactions of nucleobases. Finally, taking into account the energy and structural data reported in this work, one can realize how beautifully nature takes advantage of these non-covalent interactions to form one of the most exciting and intriguing biomolecules of all, the DNA. 


\section{Experimental Section}

General Procedures. Melting points were obtained in a Melt-temp II apparatus with an open capillary tube and are uncorrected. Nuclear magnetic resonance spectra were recorded in $\mathrm{CDCl}_{3}$ on a Jeol Eclipse 400 spectrometer at $399.8 \mathrm{MHz}$ for ${ }^{1} \mathrm{H}$ and at $100.5 \mathrm{MHz}$ for ${ }^{13} \mathrm{C}$. Chemical shifts are referred to internal $\left(\mathrm{CH}_{3}\right)_{3} \mathrm{Si}$. Mass spectra were measured on a Hewlett Packard 5989A spectrometer using electron impact (EI) at $70 \mathrm{eV}$. Microanalysis were recorded in Thermo Finnigan Flash 1112 analyzer. X-ray diffraction data were collected in an Enraf-Nonius Kappa CCD. Data collection: COLLECT software (Nonius BV 1997). ${ }^{23}$ Cell refinement and data reduction: Denzo/Scalepack sofware. ${ }^{24} \mathrm{An}$ integer system of programs was used for the solution, refinement and analysis of X-ray-diffraction data, WinGX v-1.64. ${ }^{25}$ The structures were solved by direct methods with Shelxs-97 (Sheldrick 1997) ${ }^{26}$ and refined with Shelxl-97 (Sheldrick 1997). ${ }^{27}$ Molecular graphics with WinGX software. ${ }^{25}$ All chemicals used here were of reagent grade and were obtained from Aldrich Chemical Co.

NMR experiments for thermodynamic measurements. Proton NMR spectra were taken on previously temperature calibrated instrument, with the following acquisition parameters: PW1 = $6.7 \mathrm{~s}$, Acq. Time $=2.048 \mathrm{~s}, \mathrm{SW}=8 \mathrm{kHz}$, data points $=16384$, relaxation delay $=1.6 \mathrm{~s}$.

$\mathrm{X}$-ray crystallography of the adduct 1-octylthymine/9-octyladenine. The complex was recrystallized from a solution of 1 to 1 equivalents of (1) and (2) in DMSO. Crystal data: $\mathrm{C}_{26} \mathrm{H}_{43} \mathrm{~N}_{7}, \mathrm{M}=485.67$, Triclinic, $\mathrm{P}-1, a=8.468$ (2),$b=11.312$ (3), $c=16.401$ (6) $\alpha=71.176$ (12), $\beta=78.503$ (12) $\gamma=71.175$ (16), $V=1399.4$ (7) $\AA, Z=2$, (MoKa) $\lambda=0.717073 \mathrm{~T}=293 \mathrm{~K}$, 5473 independent measured reflection, reflections $3264[(F>4 \sigma(F)]$, final $R$ indices $[F>4 \sigma(F)]$, $\mathrm{R}_{1}=0.0541, \mathrm{wR}_{2}=0.1267$. Crystallographic data (excluding structure factors) for this structure have been deposited in the Cambridge Crystallographic Centre as supplementary publication numbers CCDC 218676.

5-Methyl-1-octyl-1H-pyrimidine-2,4-dione [1-octylthymine] (1). To a mixture of $0.1 \mathrm{~g}(0.79$ $\mathrm{mmol})$ of thymine in $0.3 \mathrm{~mL}$ hexamethyldisilazane $(2.37 \mathrm{mmol})$, was added a catalytic amount of chlorotrimethylsilane. The mixture was heated to reflux and maintained at $80{ }^{\circ} \mathrm{C}$, under stirring, for $12 \mathrm{~h}$. The excess of hexamethyldisilazane was removed under vacuum $\left(50{ }^{\circ} \mathrm{C} / 1.5 \mathrm{~mm} \mathrm{Hg}\right)$ and $0.14 \mathrm{~mL}$ of 1 -bromooctane $(0.79 \mathrm{mmol})$ were added along with $0.014 \mathrm{~mL}$ of trimethylsilyl trifluoromethanesulfonate $(0.08 \mathrm{mmol})$ to the residue. When the addition was completed, the temperature of the mixture was raised to $60{ }^{\circ} \mathrm{C}$ and maintained, under stirring, for $12 \mathrm{~h}$. The crude material was transferred to a chromatographic column and eluted with a mixture of hexane/ethyl acetate (80:20). The product was obtained as colourless crystals after recrystallization from acetone, mp $121-122{ }^{\circ} \mathrm{C}$. Yield $0.151 \mathrm{~g}(80 \%) .{ }^{1} \mathrm{H} \mathrm{NMR}\left(\mathrm{CDCl}_{3}\right) \delta(\mathrm{ppm})$ : $0.86\left(3 \mathrm{H}, \mathrm{t}\right.$, chain- $\left.\mathrm{CH}_{3}\right), 1.27\left(10 \mathrm{H}, \mathrm{m}\right.$, chain- $\mathrm{CH}_{2}$ 's), $1.64\left(2 \mathrm{H}, \mathrm{m}, \mathrm{C}_{2} \mathrm{CH}_{2} \mathrm{~N}\right), 1.90(3 \mathrm{H}, \mathrm{d}, \mathrm{T}-$ $\left.\mathrm{CH}_{3}\right), 3.67\left(2 \mathrm{H}, \mathrm{t}, \mathrm{CH}_{2} \mathrm{~N}\right), 6.97(1 \mathrm{H}, \mathrm{d}, \mathrm{T}-\mathrm{CH}), 9.60(1 \mathrm{H}, \mathrm{s}, \mathrm{NH}) \mathrm{ppm} .{ }^{13} \mathrm{C} \mathrm{NMR}\left(\mathrm{CDCl}_{3}\right), \delta$ (ppm): 12.4 ( $\mathrm{T}-\mathrm{CH}_{3}$ ), 14.1 (chain- $\mathrm{CH}_{3}$ ), 22.6, 26.4, 29.1, 29.2, 30.9, 31.7, 48.6 (chain- $\mathrm{CH}_{2}$ 's), 
110.5 (C-5), 140.4 (C-6), 151.01 (C-2), 164.5 (C-4). MS, m/z $238\left(\mathrm{M}^{+}\right), 223\left(\mathrm{M}^{+}-15\right), 126\left(\mathrm{M}^{+}-\right.$ 112), 96 ( $\left.\mathrm{M}^{+}-142\right), 55\left(\mathrm{M}^{+}-183\right), 41\left(\mathrm{M}^{+}-197\right)$.

9-Octyl-9H-purin-6-ylamine [9-octyladenine] (2). To a solution of $0.1 \mathrm{~g}(0.74 \mathrm{mmol})$ of adenine in $50 \mathrm{~mL}$ of DMSO, was added $0.156 \mathrm{~g}(0.74 \mathrm{mmol})$ of tetrabutylammonium hydroxide and $0.13 \mathrm{~mL}(0.74 \mathrm{mmol})$ of 1-bromooctane. The mixture was stirred at $25{ }^{\circ} \mathrm{C}$, for $3 \mathrm{~h}$. To quench the reaction, $100 \mathrm{~mL}$ of $\mathrm{H}_{2} \mathrm{O}$ were added, the product precipitated as a white solid from the mixture and it was filtered and used without further purification. Yield $0.155 \mathrm{~g}$ (85\%). $\mathrm{mp}$ 122-123 ${ }^{\circ} \mathrm{C} .{ }^{1} \mathrm{H}$ NMR $\left(\mathrm{CDCl}_{3}\right) \delta(\mathrm{ppm}): 0.84$ (3H, t, chain- $\left.\mathrm{CH}_{3}\right), 1.27$ (10H, m, chain- $\mathrm{CH}_{2}$ 's), $1.87\left(2 \mathrm{H}, \mathrm{m}, \mathrm{CH}_{2} \mathrm{CH}_{2} \mathrm{~N}\right), 4.17\left(2 \mathrm{H}, \mathrm{d}, \mathrm{CH}_{2} \mathrm{~N}\right), 5.88\left(2 \mathrm{H}, \mathrm{s}, \mathrm{NH}_{2}\right), 7.77(1 \mathrm{H}, \mathrm{s}, \mathrm{H}-8), 8.35(1 \mathrm{H}, \mathrm{s}$, H-2) ppm. ${ }^{13} \mathrm{C}$ NMR $\left(\mathrm{CDCl}_{3}\right), \delta$ (ppm): $14.1\left(\mathrm{CH}_{3}\right), 22.6,26.7,29.1,30.1,31.8,44.0,48.6$ (chain- $\mathrm{CH}_{2}$ 's), 119.4 (C-5), 140.4 (C-8), 150.2 (C-4), 153.0 (C-2), 155.7 (C-6). MS, m/z 247 $\left(\mathrm{M}^{+}\right), 148\left(\mathrm{M}^{+}-99\right), 204\left(\mathrm{M}^{+}-43\right), 190\left(\mathrm{M}^{+}-57\right), 176\left(\mathrm{M}^{+}-71\right), 162\left(\mathrm{M}^{+}-85\right), 135\left(\mathrm{M}^{+}-112\right)$. Anal. Calc. for $\mathrm{C}_{13} \mathrm{H}_{21} \mathrm{~N}_{5}$ : C, 63.11; H 8.56; N, 28.33. Found C, 63.00; H, 8.62; N, 28.77. A crystal suitable for x-ray diffraction was obtained through recrystallization from acetonitrile. Crystal data: $\mathrm{C}_{13} \mathrm{H}_{21} \mathrm{~N}_{5}, \mathrm{M}=247.35$, Orthorhombic, $\mathrm{P} 2{ }_{1} 2_{1} 2_{1}, a=8.3746$ (2),$b=8.4248$ (2), $c=20.089$ (7) $\alpha=90.0, \alpha=\beta=\gamma, V=1417.37(7) \AA, Z=4$, (MoKa) $\lambda=0.717073 \mathrm{~T}=293 \mathrm{~K}, 3214$ independent measured reflection, reflections $2129\left[(F>4 \sigma(F)]\right.$, final $R$ indices $[F>4 \sigma(F)], R_{1}=$ $0.0508, \mathrm{wR}_{2}=0.1098$. Crystallographic data (excluding structure factors) for this structure have been deposited in the Cambridge Crystallographic Centre as supplementary publication numbers CCDC 218677.

\section{Acknowledgements}

We are grateful to Professor E. Juaristi for the careful reading of this manuscript. We thank to CONACyT for the financial support given to this work through the projects 32221-E and G32710.

\section{References}

1. Hubin, T. J.; Busch, D. H. Coord. Chem. Rev. 2000, 200-202, 5.

2. Prins, L. J.; Reinhoudt, D. N.; Timmerman, P. Angew. Chem. Int. Ed. 2001, 40, 2382.

3. Lehn, J. M. Supramolecular Chemistry: Concepts and Perspectives; VCH: Weinheim, 1995.

4. Steed, J. W.; Atwood, J. L. Supramolecular Chemistry; Wiley: New York, 2000.

5. Lehninger, A. L. Biochemistry, $2^{\text {nd }}$ Edition; Worth Publishers Inc.: New York, 1978.

6. Lewis, F. D. Science 1997, 277, 673.

7. Neidle, S. DNA Structure and Recognition; IRL Press at Oxford University Press: New York, 1994.

8. Taton, T. A.; Mirkin, C. A.; Letsinger, R. L. Science 2000, 289, 1757. 
9. So-Jung Park; Lazarides, A. A.; Mirkin, C. A.; Brazis, P. W.; Kannewurf, C. R.; Letsinger, R. L. Angew. Chem. Int. Ed. 2000, 39, 3845.

10. Pirrung, M. C. Angew. Chem. Int. Ed. 2002, 41, 1276.

11. Lippert, B. Coord. Chem. Rev. 2000, 200-202, 487.

12. Hamilton, W. H.; Ibers J. A. Hydrogen Bonding in Solids. Methods of Molecular Structure Determination; W. A. Benjamin Inc.: New York, 1968.

13. Saenger, W. Principles of Nucleic Acid Structure; Springer-Verlag: New York, 1984, Chapter 6.

14. Kyogoku, Y.; Lord, C.; Rich, A. Proc.Natl. Acad. Sci. USA 1967, 57, 250.

15. Iwahashi, H.; Sujeta, H.; Kyogoku, Y. Biochemistry 1982, 21, 631.

16. Sartorius, J.; Schneider, H. J. Chem. Eur. J. 1996, 2, 1446.

17. Gill, S. J.; Martin, D. B.; Downing, M. J. Am. Chem. Soc. 1963, 85, 706.

18. Yanson, I.; Teplisky, A.; Sukhodub, L. Biopolymers 1979, 18, 1149.

19. Lowry T. H.; Richardson, K. S. Mechanism and Theory in Organic Chemistry; $3^{\text {rd }}$ Edition; Harper Collins Publishers: New York, 1987; Chapter 2.

20. Tohnai, N.; Yoshiaki, I; Miyata, M.; Yasui, N.; Eiko, M.; Kai, Y. Bull. Chem. Soc. Jpn. 1999, 72, 851 and 1143.

21. The concentration and the temperature of the experiment were limited by the solubility of the sample and the boiling and melting point of $\mathrm{CDCl}_{3}$ (60.9 and $-64{ }^{\circ} \mathrm{C}$ respectively).

22. Joesten, M. D.; Schaad L. J. Hydrogen Bonding; Marcel Dekker, Inc: New York, 1974.

23. COLLECT Sofware Nonius BV 1997-2000.

24. Otwinnoswski, Z.; Minor, W. 1996, Procesing of X-ray Diffraction Data Collected in Oscillation Mode. Method Enzymol. 1997, 276, 307.

25. Farrugia, L. J. J. Appl. Cryst. 1999, 32, 837.

26. Sheldrick, G. M. SHELXS97. Program for the Solution of Crystal Structures. Univ. of Gottingen, Germany (1997)..

27. Sheldrick, G. M. SHELXL97. Program for the Refinement of Crystal Structures. Univ. of Göttingen, Germany (1997).. 